\title{
FACEBOOK SEBAGAI SARANA PUBLIKASI HASIL PEMBELAJARAN
}

\author{
Citra Dewi Utami \\ Program Studi Televisi dan Film, Jurusan Seni Media Rekam \\ Fakultas Seni Rupa dan Desain, Institut Seni Indonesia Surakarta \\ Citra_de@isi-ska.ac.id
}

\begin{abstract}
The learning process is an interactive activity that occurs between educators and learners, and therefore it takes a comfortable and pleasant atmosphere in living it. One effort to create such process is with the selection of models and means of learning in accordance with the character of the course and target of learning. Scientific Writing Guidance (Bimbingan Penulisan Karya Ilmiah/ BPKI) is a fourth semester course on Television and Film Study Program, Department of Recorded Media Art, Faculty of Art and Design, Indonesian Institute of the Arts at Surakarta. This classroom action research that combines Inquiry learning methods and Drilling used Facebooksocial media as a means of learning. This was used not as a medium for disseminating face-to-face material but as a media to upload student learning outcomes. The action cycle was implemented twice. The results of this study showed an average increase in the value of learning outcomes by $40 \%$ and very high learning motivation.
\end{abstract}

Keywords: Inquiry, Drilling, Facebook

\section{PENDAHULUAN}

Proses pembelajaran merupakan kegiatan interaktif yang terjadi antara pendidik dan peserta didik, oleh sebab itulah dibutuhkan suasana yang nyaman dan menyenangkan dalam menjalaninya. Salah satu upaya untuk menciptakan hal tersebut adalah dengan pemilihan model pembelajaran yang sesuai dengan karakter mata kuliah dan target pembelajarannya. Penyusunan rancangan pembelajaran tiap semester didasarkan dari evaluasi pembelajaran untuk mata kuliah yang sama pada tahun-tahun sebelumnya. Dengan demikian diharapkan terjadi peningkatan kualitas pembelajaran dari tahun ke tahun serta dapat memberikan tawaran jalan keluar permasalahanpermasalahan yang muncul pada proses pembelajaran terdahulu.

Keaktifan mahasiswa dalam membuat tulisan ilmiah dapat dilihat dari hasil karya yang ada saat ini. Sering kali dijumpai laporan tugas akhir merupakan satu-satunya karya ilmiah yang dihasilkan selama menjadi mahasiswa strata satu. Sehingga secara kualitas susunan kalimat yang ditulis mahasiswa untuk menyampaikan gagasan susah dipahami. Belum lagi persoalan plagiarisme (yang 
saat ini sedang gencar diberantas oleh seluruh elemen pendidikan). Sehingga upaya publikasi dipilih sebagai salah satu sarana mempertanggungjawabkan karya ilmiah yang ditulis karena dengan demikian publik yang akan menilai dan menjadi evaluator dalam penentuan originalitas karya.

BPKI (Bimbingan Penulisan Karya Ilmiah) merupakan mata kuliah yang melatih mahasiswa untuk dapat menuliskan proposal penelitian dalam bidang pertelevisian dan perfilman. Masih kurangnya keaktifan para mahasiswa menulis serta rasa tanggung jawab mereka terhadap apa yang ditulis merupakan permasalahan yang hingga sekarang masih membutuhkan solusi. Selama ini mahasiswa tampak hanya bertanggung jawab kepada dosen sehingga sering kali tidak terbiasa mencantumkan rujukan dengan baik. Kutipan-kutipan yang diambil tidak taat pada aturan penulisan ilmiah. Pada kasus khusus, lebih fatal lagi terdapat mahasiswa yang menyalin persis tulisan yang telah ada. Berdasarkan evaluasi-evaluasi tersebut dibuatlah penelitian tindakan kelas yang memanfaatkan media sosial guna menjalankan eksperimen pembelajaran.

Perilaku remaja dalam bermedia sosial dewasa ini dipandang sebagai penanda jaman. Keterhubungan satu dengan yang lain menghilangkan batasan ruang dan waktu. Pada kelanjutannya hasrat untuk berbagi menjadi meningkat pesat namun tanpa diimbangi literasi konten. Keinginan remaja berekspresi sering kali mengarah pada keinginan untuk terlihat eksis di antara jaringan sosialnya. Kebiasaan yang tampak adalah pembagian "status" diri yang dilakukan secara berlebihan dengan konten yang sebenarnya tidak mencerminkan kualitas dirinya sebagai seorang mahasiswa. Melalui pengamatan kebiasaan dan hobi remaja itulah muncul gagasan pemanfaatan media sosial sebagai sarana pembelajaran. Mahasiswa dilatih untuk menulis secara terus menerus melalui linimasa masing-masing setelah sebelumnya dibebaskan dalam mencari informasi segala sesuatu yang menurut mereka menarik dan sesuai dengan bidang kajian pertelevisian dan perfilman.

Facebook merupakan salah satu situs jejaring sosial paling populer di Indonesia saat ini. Sri Widowati selaku Country Director Facebook Indonesia mencatat sebanyak 88 juta pengguna aktif bulanan pada kuartal kedua tahun 2016. ${ }^{1}$ Sebagai pengingat media sosial ini dibuat oleh Mark Zuckerberg pada tahun 2004. Pada usia 12 tahun facebook telah mampu mengaktifkan sedemikian banyak pengguna. Berdasar klasifikasi yang dibuat Andreas M Kaplan dan Michael Haenlein dalam artikel berjudul "User of the World, Unite! The Challenges and Opportunities of Social Media" dijelaskan bahwa pada situs jejaring sosial user memperoleh izin untuk terkoneksi dengan cara membuat informasi sehingga dapat diakses oleh orang lain. ${ }^{2}$ Dengan demikian Facebook memiliki kemampuan untuk mempublikasikan tulisan mahasiswa kepada masyarakat luas, minimal pada orang-orang yang berada pada jaringannya. Hal ini bertujuan untuk membangun rasa tanggung jawab terhadap beragam informasi yang disampaikan. Informasi yang bermanfaat bagi orang lain, bukan hanya informasi yang ditujukan sebagai alat untuk menunjukkan eksistensi diri. Pengarsipan yang tersimpan telah dilengkapi dengan data waktu pengerjaan sehingga dapat diamati pula kedisiplinan mahasiswa dalam menjalankan proses pembelajaran. Pemanfaatan Facebook sebagai sarana pembelajaran dengan penggabungan metode inkuri dan drilling pada mata kuliah MK BPKI dapat menjadikan suasana menyenangkan bagi mahasiswa serta mampu meningkatkan keaktifan mereka dalam menulis dan bertanggung jawab terhadap apa yang ditulisnya.

\section{KAJIAN PUSTAKA}

Metodologi penelitian tindakan kelas didukung oleh motode-metode pembelajaran yang diterapkan dan dijadikan rujukan dalam kajian ini. Kesemuanya digunakan untuk saling melengkapi dalam pembahasan.

Metode Drilling menurut Sri Anitah, dalam Teknologi Pembelajaran, lebih dikenal sebagai metode latihan, cara pembelajaran yang memberikan latihan terhadap yang dipelajari sehingga peserta didik mendapatkan keterampilan tertentu. ${ }^{3}$ Mahasiswa diberikan latihan menulis melalui akun facebook masing-masing setiap kali pertemuan. Kelebihan dari model ini adalah mengaktifkan mahasiswa dalam menulis sehingga mereka menjadi 
terbiasa. Kecakapan menulis terasah dengan latihanlatihan yang selalu dilakukan. Langkah-langkah metode drilling :

\section{a. Kegiatan Dosen}

1). Mempersiapkan bahan latihan

2). Memberikan penjelasan tentang prosedur latihan

3). Memeriksan hasil latihan

4). Mengajukan kembali materi latihan

b. Kegiatan Mahasiswa

1). Mendengarkan baik-baik instruksi latihan yang disampaikan

2). Menjalankan latihan

3). Mengulang kembali latihan

Evaluasi yang dapat dilakukan dari metode pembelajaran drilling adalah dengan melihat hasil latihan mahasiswa yang terekam secara baik melalui Facebook. Tulisan-tulisan tersebut digunakan sebagai bahan analisis penelitian tindakan kelas ini. Metode ini dirasa kurang dapat menumbuhkan kreatifitas, oleh sebab itu dalam penelitian tindakan kelas ini digabungkan dengan metode inkuiri yang difungsikan sebagai pengayaan materi tulisan mahasiswa.

Metode Inkuiri dijelaskan oleh Gulo dalam buku berjudul Stategi Belajar Mengajar. Metode inkuiri berarti suatu rangkaian kegiatan belajar yang melibatkan secara maksimal seluruh kemampuan siswa untuk mencari dan menyelidiki secara sistematis, kritis, logis dan analitis sehingga siswa dapat merumuskan sendiri temuannya secara percaya diri. ${ }^{4}$ Metode ini dipilih untuk melengkapi kekurangan metode drilling. Tindakan yang diterapkan adalah meminta mahasiswa untuk membaca referensi terlebih dahulu terkait dengan materi yang telah dipilih berdasarkan ketertarikan mereka. Selanjutnya mahasiswa mencari dan menyelidiki materi tersebut secara sistematis, kritis dan logis. Hingga akhirnya mereka mampu menganalisis dan merumuskan temuannya dengan baik. Pada gilirannya ketika metode drilling dijalankan mereka telah menguasai materi dengan baik. Kreatifitas tulisan selalu terjaga melalui pembiasaan latihan menulis secara terus-menerus. Hasil belajar adalah kemampuan-kemampuan yang dimiliki siswa setelah menerima pengalaman belajar.
Hasil belajar siswa pada hakekatnya adalah perubahan mencakup bidang kognitif, afeksi, dan psikomotoris yang berorientasi pada proses belajar mengajar yang dialami siswa. ${ }^{5}$ Penilaian hasil belajar para peserta kuliah dapat dilihat melalui ketiga aspek tersebut. Gabungan dari ketiganya dapat dikonversikan menjadi sebuah penilaian yang utuh. Motivasi dipahami sebagai sebuah dorongan atau arahan yang berasal dari bahasa Latin "movere". Dorongan yang terkait dengan cara untuk mengarahkan potensi dan kemampuan mahasiswa agar menjadi lebih produktif guna mencapai tujuan yang telah ditargetkan. Upaya dirancang untuk mengarahkan seseorang melakukan sesuatu demi mencapai tujuan tertentu.

Hipotesis merupakan prediksi atau jawaban sementara atas rumusan masalah penelitian. Dikatakan sementara karena jawaban yang diberikan baru didasarkan pada teori yang relevan, belum didasarkan pada fakta-fakta empiris yang diperoleh melalui pengumpulan data. Jadi hipotesis juga dapat dinyatakan sebagai jawaban teoritis terhadap rumusan masalah penelitian, belum jawaban yang empirik dengan data. ${ }^{6}$ Hipotesis merupakan prediksi dan baru terbukti setelah datadata temuan penelitian terhimpun.

\section{METODE PENELITIAN}

Metode yang sesuai untuk mendedah kajian ini adalah eksperimen yang dilakukan secara berulang, dengan dua siklus. Perlakuan yang digunakan pada eksperimen ini adalah penerapan gabungan metode pembelajaran Inkuiri dan Drilling dalam pembelajaran mata kuliah "Bimbingan Penulisan Karya Ilmiah pada Program Studi Televisi dan Film, Jurusan Seni Media Rekam, Fakultas Seni Rupa dan Desain, Institut Seni Indonesia Surakarta. Eksperimen ini bersifat "sebelum -sesudah", yaitu dengan membandingkan motivasi belajar dan nilai hasil belajar sebelum dan sesudah menggunakan metode pembelajaran terpilih. Eksperimen tindakan kelas ini menggunakan model dua siklus dengan masing-masing siklus terdiri atas 4 tahapan yaitu: ${ }^{7}$
a. Perencanaan tindakan
b. Pelaksanaan tindakan
c. Observasi dan interpretasi
d. Refleksi tindakan 
Pelaksanaan tindakan didokumentasi dengan menggunakan media perekaman video guna menunjang pelaksanaan observasi dan interpretasi. Subjek eksperimen 10 orang mahasiswa.

\section{PENGUMPULAN DATA}

Teknik pengumpulan data merupakan proses yang sistematis untuk memperoleh dan mengukur informasi dari variabel-variabel yang diteliti, guna menjawab rumusan masalah, menguji hipotesis, dan mengevaluasi hasil. ${ }^{8}$ Setiap siklus menggunakan tiga teknik pengumpulan data, yaitu observasi yang digunakan dalam penelitian ini adalah observasi yang berperan serta. ${ }^{9}$ Peneliti merupakan pengampu mata kuliah, sehingga terlibat langsung dalam proses pembelajaran. Dokumentasi digunakan untukmelihat hasil eksperimen. Kegiatan terdokumentasikan secara digital melalui media sosial. Tulisan mahasiswa pada linimasa Facebook masing-masing sebagai hasil dari eksperimen yang dilakukan. Screenshot dari aplikasi tersebut menjadi data yang dapat dianalisis lebih lanjut. Foto-foto pelaksanaan penelitian juga dimanfaatkan sebagai data pendukung. Dan Focused Groups Discussion (FGD) dimanfaatkan sebagai sarana pengungkapan materi pengembangan rencana tindakan pada siklus yang kedua. Dosen sebagai pengamat ${ }^{10}$ pada proses FGD memperoleh informasi secara menyeluruh

\section{HASIL}

Pengujian tindakan yang diyakini dapat mengatasi masalah atau dapat meningkatkan efektifitas dan efesiensi kerja dilakukan dalam kajian ini. Tidak dilakukannya penelitian mulai dari penemuan masalah dan potensi merupakan ciri dari penelitian tindakan kelas level 2. Kondisi awal telah diketahui dan dimulai dengan penyelenggaraan tes awal sebelum dilaksanakannya tindakan. Hasil pretest digunakan sebagai data terkait dengan kondisi sebelum diberikannya perlakuan-perlakuan pada proses eksperimen.

\section{Sebelum Tindakan}

Perencanaan yang sistematis dibutuhkan dalam memulai penelitian tindakan kelas. Penerapan prosedur yang berurutan sehingga prosesnya berjalan dengan baik. Pada penelitian tindakan kelas mengandung unsur pengidentifikasian masalah, prediksi solusi, pengimplementasian solusi, observasi dan interpretasi terhadap pengaruh perlakuan pada eksperimen yang dilakukan, pemodifikasian tindakan dan ide-ide dalam kerangka evaluasi, serta perencanaan untuk tindakan berikutnya. Untuk memulai penelitian tindakan kelas biasanya dikelompokkan dalam tiga bagian, yaitu persiapan, implementasi, dan implikasi. ${ }^{11}$

\section{a. Persiapan}

1) Menentukan permasalahan

2) Memprediksi solusi

3) Mengimplementasikan solusi

4) Evaluasi solusi

b. Implementasi Praktis

1) Mulai dari yang kecil

2) Rencanakan secara hati-hati

3) Libatkan orang lain

4) Kontribusi dosen

5) Umpan balik dari mahasiswa

c. Implikasi Tindakan

1) Pikiran berubah

2) Kekeliruan bisa kapan saja terjadi

a) Lancar seperti yang direncanakan

b) Tidak lancar di awal dan mudah di akhir

c) Menghadapi tantangan lebih dahulu baru lancar

Sarana yang disiapkan pada awal pelaksanaan penelitian adalah dengan membuat akun Facebookyang didahului dengan pembuatan alamat email@gmail.com. Kegiatan sebelum tindakan diberikan yaitu dengan diselenggarakannya pretest. Penilaian ujian awal ini digunakan sebagai nilai sebelum tindakan kelas dilakukan.

\section{Pelaksanaan Pembelajaran dengan Penggabungan Inkuiri dan Drilling.}

Penelitian tindakan kelas ini menggabungkan dua metode pembelajaran dalam pelaksanaannya. Metode inkuri dan drilling dikombinasikan untuk menemukan jalan keluar permasalahan keaktifan mahasiswa menulis serta kurangnya kesadaran mereka penyertaan rujukan saat menulis ilmiah. 
Penggabungan kedua metode pembelajaran terpilih ditujukan untuk saling melengkapi. Tindakan yang diterapkan pada proses inkuiri adalah meminta mahasiswa untuk memilih dan membaca referensi terlebih dahulu berdasarkan ketertarikan mereka pada bidang pertelevisian dan perfilman. Selanjutnya mahasiswa diarahkan untuk mencari dan menyelidiki tema pilihan tersebut secara sistematis, kritis dan logis. Hingga pada akhirnya mereka mampu menganalisis dan merumuskan temuannya dengan baik. Pada gilirannya ketika metode drilling dijalankan mereka telah menguasai materi dengan baik. Kreatifitas tulisan selalu terjaga melalui pembiasaan latihan menulis secara terus menerus.

Pembiasan latihan menulis melalui drilling dengan sarana kekinian (akun media sosial). Mahasiswa dilatih menulis melalui akun facebook masing-masing setiap kali pertemuan. Kelebihan dari model ini adalah meningkatkan keaktifan mahasiswa dalam menulis sehingga mereka menjadi terbiasa. Kecakapan menulis terasah dengan latihan-latihan yang selalu dilakukan. Berikut adalah langkahlangkah penggabungan inkuiri dan drilling yang telah dilaksanakan :

\section{a. Kegiatan Dosen}

1). Persiapan bahan latihan disajikan secara terbuka dan luas di perpustakaan. Pertemuan dilaksanakan di perpustakaan Fakultas Seni Rupa dan Desain, sehingga peserta dapat leluasa memilih buku-buku referensi sesuai dengan ketertarikan mereka. Kebebasan pemilihan materi serta penelurusan secara mandiri guna pengayaan materi yang dipilih merupakan ciri khas dari metode inkuiri.

2). Prosedur latihan disampaikan pada bagian akhir proses pencarian buku referensi. Hal ini ditujukan untuk memberikan ruang bebas dalam mengembangankan materi yang disukai para peserta. Inkuiri memberikan kesempatan peserta untuk mencari tahu terlebih dahulu materi apa yang dipilih sehingga prosesnya menjadi lebih terbuka.

3). Pemeriksaan hasil latihan dilakukan melalui pengamatan terhadap review bacaan yang telah dituliskan pada laman media sosial masingmasing peserta. Masing-masing peserta diminta untuk menuliskan review atas temuan-temuan yang didapat pada tiap pertemuan. Pembiasaan inilah yang merupakan kekhasan dari metode drilling. Semua hasil latihan terekam dengan baik secara digital. Tenggat waktu yang ditentukan juga terjaga karena adanya pemberitahuan kapan peserta mengunggah tulisannya. Ketertiban peserta terhadap waktu pengumpulan juga merupakan indikator penilaian.

4). Pengajuan kembali materi latihan dilaksanakan secara bertahap sesuai dengan rancangan penelitian pada tiap-tiap pertemuan. Pengulangan-pengulangan dilakukan untuk membiasakan peserta terhadap metode pembelajaran selama satu semester.

\section{b. Kegiatan Mahasiswa}

1). Peserta perkuliahan sebagai subjek penelitian mendengarkan baik-baik instruksi latihan yang disampaikan oleh dosen pengampu terkait dengan proses pembelajaran. Pemahaman tentang penjelasan ini penting karena proses belajar mengajar mata kuliah teori tidak hanya menitikberatkan pada metode ceramah. Penggabungan dua metode pembelajaran dapat berjalan baik berkat kerja sama antara peserta perkuliahan dan pengampu mata kuliah. Meskipun pada awalnya banyak yang menanyakan pentingnya penelitian ini, pada akhirnya mahasiswa memahami manfaatnya bagi mereka.

2). Pelaksanaan pencarian buku referensi pada awalnya diwarnai dengan kebingungan para peserta, hal tersebut dikarenakan belum terlatihnya para mahasiswa membaca secara rutin. Mahasiswa belum memiliki bayangan apa yang penting untuk dibaca sesuai dengan minat mereka. Pembiasaan peserta untuk mencari dan menelusuri referensi dijalankan melalui penggabungan metode ini.

3). Pengulangan latihan membaca referensi guna mengembangkan tema terpilih menjadi materi penelitian ilmiah. Setiap pertemuan diawali dengan pemilihan buku referensi, membaca, menuliskan review, dan dilanjutkan dengan proses penulisan karya ilmiah. Proses tersebut 
dilakukan secara berulang-ulang sebagai bagian dari pembiasaan.

\section{c. Tentang Facebook}

Facebook termasuk jenis situs jejaring sosial di mana user memperoleh izin untuk terkoneksi dengan cara membuat informasi yang bersifat pribadi, kelompok atau sosial sehingga dapat terhubung atau diakses oleh orang lain. Para peserta dan dosen pengampu terhubung dalam berbagi hasil belajar. Konten yang bisa diunggah antara lain, tulisan, gambar, tautan, dan video. Informasi yang dapat diambil antara lain waktu pengunggahan. Serta dapat menghubungkan pula dengan pengambil kebijakan, misalnya ketua program Studi. Pemilihan media sosial sebagai sarana pembelajaran tanggung jawab diri terhadap publik menjadi tepat karena sifatnya yang saling menghubungkan, serta diberikannya pemberitahuan tentang informasi yang ditujukan terhadap seorang pengguna. Ciri khas dari media sosial sebagai berikut ini :

1) Konten yang disampaikan dibagikan kepada banyak orang dan tidak terbatas pada satu orang tertentu;

2) Tidak ada gerbang penghambat;

3) Isi disampaikan secara online dan langsung;

4) Konten dapat diterima secara online dalam waktu lebih cepat (bisa juga tertunda penerimaannya, tergantung pada waktu interaksi yang ditentukan sendiri oleh pengguna);

5) Media sosial menjadikan penggunanya sebagai kreator dan aktor yang memungkinkan dirinya beraktualisasi diri;

6) Dalam konten media sosial terdapat sejumlah aspek fungsional seperti identitas, berbagi (sharing), hubungan (relasi), dan saling dapat merespon (interaktif).

\section{Siklus Pertama}

a. Perencanaan Pengujian

Tahap ini disiapkan rencana pembelajaran yang meliputi :

1) Rencana Pelaksanaan Pembelajaran
2) Sistem Penilaian

3) Lembar Penilaian

b. Pelaksanaan Tindakan

Pada siklus I, proses pembelajaran dilakukan dengan urutan kegiatan:

1) Pretest

2) Penjelasan proses pembelajaran

3) Pemilihan tema

4) Pencarian referensi

5) Membaca buku

6) Menuliskan review

7) Penyampaian materi perkuliahan dan penugasan

8) Penulisan Proposal Karya Ilmiah sebagai posttest

\section{c. Obsevasi dan Interpretasi}

Kegiatan observasi dilakukan peneliti secara langsung bersamaan dengan proses pembelajaran. Pengamatan difokuskan pada aktifitas mahasiswa dan interaksinya dengan pengampu. Berikut ini adalah data hasil pembelajaran mahasiswa pada siklus I, yaitu:

\section{1) Kegiatan membaca}

Tiap tatap muka diawali dengan membaca satu buku selama 15 menit. Pemilihan buku disesuaikan dengan tema yang diminati. Pada awalnya peserta bingung mimilih buku, hal tersebut dikarenakan tidak terbiasanya peserta dengan kegiatan membaca. Hal tersebut dibuktikan dengan kecepatan membaca yang rendah. Waktu yang diberikan awalnya dirasa tidak cukup. Namun pada pertemuan-pertemuan selanjutnya para peserta menjadi semakin terbiasa dalam kegiatan membaca. Peserta dapat dengan cepat membaca bagian-bagian yang penting guna pengayaan dari tema yang diminati.

2) Memilih Tema

Para peserta diberikan kebebasan dalam memilih tema penelitian sesuai dengan minat masingmasing dalam bidang Pertelevisian dan Perfilman. Hal tersebut didasarkan pada 
pertimbangan kemampuan mahasiswa dalam mengukur diri. Pertimbangan yang diberikan adalah dengan menilik nilai-nilai mata kuliah lain yang telah ditempuh sebelumnya. Objek kajian yang dipilih bisa program televisi maupun karya film. Pada awalnya beberapa mahasiswa memilih tema tentang tata kelola institusi pertelevisian dan perfilmnan, teknis pembuatan program dan film, serta kajian teks program televisi dan film.

3) Menuliskan review dari kegiatan membaca

Kegiatan membaca tidak berhenti sebatas selesai membaca, namun diikuti dengan menuliskan pemahaman mereka atas apa yang telah dibaca.

4) Pencarian konsep dasar, landasan teori, tinjauan pustaka.

\section{d. Refleksi Tindakan}

Hasil Pengamatan selama proses eksperimen menunjukkan bahwa dengan perlakuan yang diterapkannya penggabungan antara inkuiri dan drilling terhadap mahasiswa terutama pada aspek perasaan senang, keaktifan menulis dan ketertarikan terhadap pembelajaran matakuliah BPKI mengalami peningkatan, sehingga pada gilirannya dibuktikan dengan peningkatan nilai hasil belajarnya. Hal ini menunjukkan bahwa penerapan gabungan metode inkuiri dan drilling pada siklus I dapat meningkatkan motivasi dan nilai hasil belajar. Hasil refleksi pada siklus I tersebut selanjutnya akan diuji konsistensinya pada siklus II.

Berikut adalah rekapitulasi penilaian hasil pembelajaran dan pengamatan motivasi belajar peserta:

\begin{tabular}{|c|c|c|c|}
\hline Peserta & Sebelum & Siklus I & Siklus II \\
\hline RP & 2,5 & 2,5 & 3 \\
\hline AN & 2 & 2,5 & 3 \\
\hline HM & 2,5 & 3 & 3 \\
\hline LY & 2 & 2,5 & 3 \\
\hline NK & 2 & 2,5 & 3 \\
\hline SS & 2 & 2,5 & 3 \\
\hline AP & 3,5 & 3,75 & 4 \\
\hline ED & 3 & 3,5 & 4 \\
\hline AT & 2 & 2,5 & 3 \\
\hline VW & 2,5 & 3 & 3 \\
\hline
\end{tabular}

Tabel 1. Perbandingan hasil pembelajaran saat sebelum, setelah siklus I, dan setelah siklus II

\begin{tabular}{|l|c|c|c|}
\hline \multicolumn{1}{|c|}{ Keterangan } & Sebelum & Siklus & Siklus II \\
I & & \\
\hline ST = Sangat Tinggi & $0 \%$ & $20 \%$ & $20 \%$ \\
\hline T = Tinggi & $20 \%$ & $40 \%$ & $60 \%$ \\
\hline C = Cukup & $40 \%$ & $40 \%$ & $20 \%$ \\
\hline R = Rendah & $40 \%$ & $0 \%$ & $0 \%$ \\
\hline
\end{tabular}

Tabel 2. Perbandingan hasil pengamatan motivasi belajar sebelum, setelah siklus I, dan setelah siklus II.

\section{PEMBAHASAN}

Hasil belajar merupakan kemampuankemampuan yang dikuasai oleh peserta perkuliahan setelah melalui proses pembelajaran. Cakupan dari hasil belajar seorang mahasiswa pada hakikatnya mencakup bidang kognitif, afeksi, dan psikomotoris. Secara kognitif, peserta kuliah dapat memahami dan memperkaya tema bahasan terkait bidang pertelevisian dan perfilman. Pengetahuan mereka bertambah setelah melakukan penelusuran secara mandiri dan dilakukan berulang-ulang. Penambahannya perlahan namun dapat dengan kuat tertanam pada pikiran mereka. Aspek afeksi yang dihasilkan adalah peserta perkuliahan menjadi lebih jujur terhadap rujukan apa yang ditulisnya. Mahasiswa dituntut untuk menghasilkan tulisan yang benar-benar hasil kerja mereka sendiri. Pengulangan-pengulangan kegiatan yang dilakukan selama proses pembelajaran menjadikan aspek psikomotorik mereka terasah dengan baik, sehingga menjadi terbiasa menulis. Kebiasaan menulis di media sosial yang biasanya tidak ilmiah diarahkan pada pembiasaan menulis ilmiah. Facebook merupakan aplikasi yang cukup dekat dengan mahasiswa.

Kelebihan penggunaan Facebook dalam pembelajaran di antaranya adalah memungkinkan penyertaan lampiran berupa gambar dan tautan lain untuk kelengkapan tulisan, pemberian respon secara langsung (baik dari pengampu, peserta, dan publik), 
memberikan pengaruh kepada orang lain secara luas, dapat saling membaca tulisan teman dan memberi respon, dan terlacaknya tanggal pengunggahan data yang terekam sejak dimulainya tindakan hingga akhir.

Hasil pembelajaran sebelum pelaksanaan tindakan, setelah siklus I, dan setelah siklus II menunjukkan terjadi peningkatan. Konsistensi peningkatan tampak dari hasil penilaian setelah siklus I dan siklus II. Pada siklus I terdapat 90\% peserta nilainya meningkat, dan tidak ada penurunan setelah siklus II. Hal ini menunjukkan konsistensi peningkatan hasil pembelajaran. Penambahan nilai dari hasil siklus II juga terjadi sebanyak $80 \%$ peserta dibanding pada siklus I. Pada siklus II tidak ada penurunan nilai hasil pembelajaran.

Prosentase hasil pengamatan motivasi belajar peserta penelitian tindakan kelas ini menunjukkan terjadinya peningkatan yang konsisten. Berdasarkan penghitungan yang dilakukan terjadi penurunan prosentase peserta yang bermotivasi rendah, yaitu dari $20 \%$ saat sebelum dilaksanakannya tindakan menjadi $0 \%$ setelah selesai siklus I dan siklus II. Untuk peserta yang bermotivasi cukup konsisten dari sebelum tindakan hingga akhir siklus I, namun menurun saat setelah siklus II. Peserta dengan motivasi tinggi menunjukkan peningkatan yang signifikan. Dari hanya 20\%, meningkat menjadi $40 \%$ setelah siklus I dan meningkat kembali menjadi $60 \%$ setelah siklus II. Dan motivasi peserta menunjukkan peningkatan dari 0\% menjadi $20 \%$ pada siklus I dan konsisten hingga siklus II.

\section{KESIMPULAN}

Penelitian tindakan kelas yang dilaksanakan dalam kurun waktu satu semester ini melibatkan peserta Mata Kuliah Bimbingan Penulisan Karya Ilmiah pada Program Studi Televisi dan Film, Jurusan Seni Media Rekam, Fakultas Seni Rupa dan Desain, Institut Seni Indonesia Surakarta. Pengambilan data penelitian ini terbagi menjadi dua siklus, masingmasing siklus mencakup tahap perencanaan tindakan selama satu kali pertemuan, tahap pelaksanaan tindakan selama empat kali pertemuan, tahap observasi dan interpretasi selama satu kali pertemuan, dan tahap refleksi tindakan sebanyak satu kali pertemuan. Beberapa kesimpulan yang dapat ditarik dari hasil penelitian ini adalah:

1. Nilai hasil belajar saat pretest menunjukkan rerata 2,4 .

2. Motivasi belajar sebelum tindakan tidak ada yang masuk dalam kategori sangat tinggi dan terdapat peserta bermotivasi rendah.

3. Langkah-langkah penerapan gabungan metode inkuiri dan drilling berhasil dalam meningkatkan nilai pembelajaran pada mata kuliah Bimbingan Penulisan Karya Ilmiah.

4. Rerata nilai hasil belajar sesudah dijalankannya siklus I adalah 2,83 dan setelah siklus II adalah 3,2 .

5. Motivasi belajar sesudah tindakan menunjukkan tidak adanya peserta bermotivasi rendah.

6. Persentase peningkatan rerata nilai sebesar $40 \%$. 


\section{DAFTAR PUSTAKA}

Basroni dan Suwandi. 2008. Prosedur Penelitian Tindakan Kelas. Bogor: Ghalia Indonesia.

Gulo. 2002. Strategi Belajar Mengajar. Jakarta: Grasindo.

Lexy J. Moleong. Metode Penelitian Kualitatif. Bandung:PT Remaja Rosdakarya.

Majalah Business Horizons. 2010.

Mytton, Graham. 2001. Pengantar Riset Khalayak. Diterjemahkan oleh Tim Jaring Line. UNICEF.

Sri Anitah. 2009. Teknologi Pembelajaran. Surakarta: Yuma Pustaka.

Sugiyono. 2015. Metode Penelitian Tindakan Komprehensif; Untuk Perbaikan Kinerja dan Pengembangan Ilmu Tindakan. Bandung: Alfabeta.

Sukardi.2015. Metode Penelitian Pendidikan Tindakan Kelas; Implementasi dan Pengembangannya. Jakarta: Bumi Aksara.

http://tekno.kompas.com/read/2016/10/20/ 17062397/ diakses pada tanggal 20 Februari 2017 pukul 03:22

\footnotetext{
(Footnotes)

${ }^{1}$ http://tekno.kompas.com/read/2016/10/20/17062397/ diakses pada tanggal 20 Februari 2017 pukul 03:22

${ }^{2}$ Majalah Business Horizons. 2010. hal. 68-69
}

${ }^{3}$ Sri Anitah.2009. Teknologi Pembelajaran. Surakarta: Yuma Pustaka, hal.118

${ }^{4}$ Gulo. 2002. Strategi Belajar Mengajar. Jakarta:

Grasindo.

${ }^{5}$ Sudjana.2005. dalam Sugiyono. 2015, hal 440.

${ }^{6}$ Sugiyono. 2015, hal 121.

${ }^{7}$ Basroni dan Suwandi. 2008. Prosedur Penelitian

Tindakan Kelas . Bogor: Ghalia Indonesia.

${ }^{8}$ Sugiyono. 2015. Metode Penelitian Tindakan

Komprehensif; Untuk Perbaikan Kinerja dan

Pengembangan Ilmu Tindakan. Bandung: Alfabeta, hal 235.

${ }^{9}$ Lexy J. Moleong. Metode Penelitian Kualitatif.

Bandung: PT Remaja Rosdakarya, hal 117

${ }^{10}$ Sukardi. 2015. Metode Penelitian Pendidikan Tindakan Kelas; Implementasi dan Pengembangannya. Jakarta:

Bumi Aksara, hal 113.

${ }^{11}$ Sukardi. 2015, hal 57. 